\title{
KOMPUTERISASI PENENTUAN TEBAL PERKERASAN KAKU DENGAN METODE AASHTO 1993
}

\author{
Andri Suryadi ${ }^{1}$, Budi Hartanto Susilo ${ }^{2}$ \\ ${ }^{1}$ Alumnus Program Studi Sarjana Teknik Sipil \\ Jl. Prof. drg. Suria Sumantri, MPH., No. 65, Bandung, 40164 \\ E-mail: andri.suryadi30@gmail.com \\ ${ }^{2}$ Guru Besar Program Studi Sarjana Teknik Sipil \\ Jl. Prof. drg. Suria Sumantri, MPH., No. 65, Bandung, 40164 \\ E-mail: budiharsus@yahoo.com
}

\begin{abstract}
ABSTRAK
Perhitungan tebal perkerasan secara komputerisasi perlu dikembangkan untuk meminimalisir kesalahan, memperoleh hasil yang lebih teliti, cepat, akurat, dan dapat dilakukan secara iterasi. Tujuan penelitian ini adalah menganalisis kebutuhan tebal perkerasan kaku pada ruas jalan tol dengan menggunakan metode AASHTO 1993. Nilai faktor yang digunakan dalam perhitungan, diperoleh dari proyek Jalan Tol Cikopo-Palimanan dan kekurangannya diasumsikan sesuai dengan aturan AASHTO 1993. Hasil analisis penentuan tebal perkerasan kaku diperoleh tebal sebesar $39 \mathrm{~cm}$ untuk Jalan Tol Cipali. Model untuk penentuan tebal perkerasan $W_{18}$ nominal adalah $\log 10(2541530993,12)$, yang berarti bahwa logaritma dari total kumulatif beban 18-kip ESAL yaitu 9,41. Perhitungan beban gandar standar kumulatif menggunakan metode AASHTO 1993 dengan $W_{18}$ desain diperoleh hasil sebesar 8,97, yang berarti bahwa tebal pelat beton rencana dapat diterapkan pada ruas Jalan Tol Cipali sesuai dengan toleransi yang diberikan AASHTO 1993.
\end{abstract}

Kata kunci: Perkerasan Kaku, AASHTO 1993, Komputerisasi, Jalan Tol Cipali, Toleransi.

\begin{abstract}
Computerized about calculation of pavement thickness needs to be developed to minimize the human error, obtain the results more conscientious, fast, accurate, and can be done iteratively. The purpose of this study was to analyze the necessary of rigid pavement thickness for the toll road using AASHTO 1993 method. Value factors used in the calculation, obtained from Toll Road project Cikopo-Palimanan and shortcomings assumed in accordance with the rules of AASHTO 1993. The results of the analysis of the determination of the rigid pavement thickness obtained by 39 centimeters thick for Cikampek-Palimanan Toll Road. The model for determining the pavement thickness $W_{18}$ nominal is log10 $(2541530993,12)$, which means that the logarithm of the total cumulative load of 18-kips ESAL is 9,41. Cumulative standard axle load calculations using the 1993 AASHTO method within $W_{18}$ design the result obtained was 8,97, which means that the concrete slab thickness plan will be put on Cikampek-Palimanan toll road segment in accordance with the tolerance of AASHTO 1993.
\end{abstract}

Keywords: Rigid Pavement, AASHTO 1993, Computerized, Cipali Toll Road, Tolerance.

\section{PENDAHULUAN}

\subsection{Latar Belakang}

Salah satu metode perencanaan tebal perkerasan jalan yang sering digunakan ialah metode AASHTO 1993. Metode tersebut telah dipakai secara umum di seluruh dunia untuk perencanaan serta diadopsi sebagai standar perencanaan di berbagai negara. 
Metode AASHTO 1993 pada dasarnya adalah metode perencanaan yang didasarkan pada metode empiris.

Seiring perkembangan zaman, pertumbuhan lalu lintas semakin meningkat sehingga menyebabkan beban dan volume lalu lintas yang harus didukung oleh struktur perkerasan jalan juga semakin meningkat. Perkerasan jalan merupakan struktur yang tersusun dari beberapa lapisan dan dibangun di atas tanah dasar. Struktur perkerasan jalan harus mampu mendistribusikan beban dari roda kendaraan sehingga struktur tanah di bawahnya yang lebih lunak tidak mudah rusak karena mengalami tegangan dan regangan yang berlebihan oleh beban berulang.

Tebal lapisan perkerasan jalan perlu dikembangkan, dengan cara perhitungan secara komputerisasi untuk memperoleh nilai-nilai lapisan jalan yang akurat, ideal, cermat, dan cepat. Parameter maupun indeks yang diperlukan dalam analisis empiris perkerasan jalan berdasarkan pada AASHTO 1993. Untuk memperoleh hasil analisis penelitian yang cepat dan cermat kiranya perlu disusun perhitungan komputerisasi sederhana dengan perangkat lunak Microsoft Excel dalam rangka kemudahan iterasi perhitungan yang cepat dan tepat seperti yang diharapkan oleh perencana.

\subsection{Tujuan}

Tujuan penelitian ini adalah:

1. Penyusunan secara komputerisasi faktor-faktor yang mempengaruhi pendekatan empiris dalam desain struktur perkerasan kaku suatu ruas jalan;

2. Menghitung kebutuhan tebal perkerasan kaku jalan dengan menggunakan metode AASHTO 1993 secara komputerisasi.

\subsection{Ruang Lingkup}

Pembatasan masalah dalam penelitian ini adalah:

1. Perencanaan perkerasan kaku hanya untuk jalan baru;

2. Nilai faktor-faktor yang digunakan dalam perhitungan diambil dari Jalan Tol Cipali dan kekurangannya diasumsikan sesuai dengan aturan AASHTO 1993;

3. Menghitung secara komputerisasi terhadap kebutuhan tebal perkerasan kaku;

4. Kendaraan dalam analisis perhitungan meliputi jenis kendaraan niaga, yaitu bus, truk, dan trailer;

5. Metode analisis yang digunakan adalah metode AASHTO 1993. 


\section{TINJAUAN PUSTAKA}

\subsection{Definisi Perkerasan Kaku}

Perkerasan kaku adalah struktur yang terdiri atas pelat kaku yang bersambung (tidak menerus) tanpa atau dengan tulangan, atau menerus dengan tulangan, terletak di atas lapis pondasi bawah atau tanah dasar, tanpa atau dengan lapis permukaan beraspal (Suhaili, 2003). Pada perkerasan kaku, daya dukung perkerasan terutama diperoleh dari pelat beton. Sifat, daya dukung, dan keseragaman tanah dasar sangat mempengaruhi keawetan dan kekuatan perkerasan kaku.

\subsection{Parameter Desain Perkerasan Kaku}

Terdapat beberapa parameter dalam menentukan tebal perkerasan kaku, antara lain: tanah dasar, lapisan pondasi bawah, material beton semen, lalu lintas, indeks permukaan, nilai reliabilitas, faktor kehilangan daya dukung, koefisien pelimpahan beban, dan koefisien drainase.

\section{Tanah Dasar}

Sebagian besar beban pada perkerasan kaku dipikul oleh pelat beton, tetapi keawetan dan kekuatan pelat tersebut sangat dipengaruhi oleh sifat, daya dukung, dan keseragaman tanah dasar. Keseragaman daya dukung tanah dasar akan membantu menurunkan pengaruh tegangan pada slab beton.

\section{A. CBR Tanah Dasar}

CBR merupakan suatu perbandingan antara beban percobaan (test load) dengan beban standar (standard load) dan dinyatakan dalam persentase. Harga CBR adalah nilai yang menyatakan kualitas tanah dasar dibandingkan dengan bahan standar berupa batu pecah yang mempunyai nilai CBR sebesar 100\% dalam memikul beban (U.S Army Corps of Engineers, 1985).

\section{B. Modulus Reaksi Tanah Dasar}

Parameter yang paling umum digunakan untuk menyatakan daya dukung tanah dasar pada perkerasan kaku adalah modulus reaksi tanah dasar (k). Modulus reaksi tanah dasar ditetapkan di lapangan dengan pengujian pelat bearing, dengan diameter pelat $76 \mathrm{~cm}$ yang dinyatakan dalam $\mathrm{kg} / \mathrm{cm}^{3}(\mathrm{MPa} / \mathrm{m})$. Karena pengujian "pelat bearing" memerlukan waktu lama dan biaya mahal, maka $\mathrm{k}$ dapat diperkirakan dari nilai CBR, baik CBR insitu sesuai SNI 03-1731-1989 atau CBR laboratorium sesuai SNI 03-1744- 
1989. Dari nilai CBR representatif ini kemudian diprediksi modulus elastisitas tanah dasar dengan menggunakan Persamaan 1.

$$
M_{R}=1500 \times C B R
$$

dengan:

$M_{R} \quad: \quad$ Modulus reaksi tanah dasar (psi).

CBR : $\quad$ Nilai CBR tanah dasar (\%).

\section{Beton Kurus}

Lean concrete atau disebut beton kurus fungsinya hanya sebagai lantai kerja agar air semen tidak meresap ke dalam lapisan bawahnya. Campuran material berbutir dan semen dengan kadar yang rendah. Digunakan sebagai lapis pondasi untuk perkerasan beton. Campuran Beton Kurus (CBK) harus mempunyai kuat tekan beton karakteristik pada umur 28 hari minimum $5 \mathrm{MPa}\left(50 \mathrm{~kg} / \mathrm{cm}^{2}\right)$ tanpa menggunakan abu terbang, atau $7 \mathrm{MPa}\left(70 \mathrm{~kg} / \mathrm{cm}^{2}\right)$ bila menggunakan abu terbang. Tebal campuran beton kurus ini minimum $10 \mathrm{~cm}$ dan pada dasarnya terbuat dari beton dengan mutu K-175.

\section{Material Beton Semen}

Menurut ASTM C-78, kekuatan beton harus dinyatakan dalam nilai kuat tarik lentur (flexural strength) umur 28 hari, yang didapat dari hasil pengujian balok dengan pembebanan tiga titik yang besarnya secara tipikal sekitar $3-5 \mathrm{MPa}\left(30-50 \mathrm{~kg} / \mathrm{cm}^{2}\right)$. Kuat tarik lentur beton yang diperkuat dengan bahan serat penguat seperti serat baja, aramit atau serat karbon, harus mencapai kuat tarik lentur 5-5,5MPa $\left(50-55 \mathrm{~kg} / \mathrm{cm}^{2}\right)$. Kekuatan rencana harus dinyatakan dengan kuat tarik lentur karakteristik yang dibulatkan hingga $0,25 \mathrm{MPa}\left(2,5 \mathrm{~kg} / \mathrm{cm}^{2}\right)$ terdekat.

\section{A. Modulus Elastisitas Beton}

Modulus elastis beton dapat dihitung menggunakan Persamaan 2.

$$
E_{c}=57000\left(f_{c}\right)^{0,5}
$$

dengan:

Ec : $\quad$ Modulus elastisitas beton (psi).

$f_{c}^{\prime} \quad: \quad$ Kuat tekan beton (psi).

\section{B. Modulus Kelenturan Beton}

Modulus kelenturan beton hanya digunakan untuk perencanaan perkerasan kaku. Nilai modulus kelenturan beton yang digunakan adalah nilai rata-rata kekuatan tarik 
lentur pada usia 28 hari. Jika digunakan konstruksi yang spesifik, maka dalam penentuan modulus kelenturan betonnya ada beberapa hal yang perlu

dipertimbangkan. Dihitung menggunakan Persamaan 3.

$$
S_{c}^{\prime}=S_{c}+\mathrm{z}\left(S_{D S}\right)
$$

dengan:

$S_{c}{ }_{c} \quad: \quad$ Modulus kelenturan beton (psi).

$S_{c} \quad: \quad$ Konstruksi spesifik pada modulus kelenturan beton (psi).

$S_{D S} \quad: \quad$ Standar deviasi modulus kelenturan beton (psi).

z : Variasi normal standar,

$=0,841$, untuk Percent Serviceability $(\mathrm{PS})=20 \%$

$=1,037$, untuk PS $=15 \%$

$=1,282$, untuk PS $=10 \%$

$=1,645$, untuk PS $=5 \%$

$=2,327$, untuk PS $=1 \%$

\section{Lalu Lintas}

Penentuan beban lalu lintas rencana untuk perkerasan kaku, dinyatakan dalam jumlah sumbu kendaraan niaga (commercial vehicle), sesuai dengan konfigurasi sumbu pada lajur rencana selama umur rencana. Kendaraan yang ditinjau untuk perencanaan perkerasan kaku adalah yang mempunyai berat total minimum 5ton. Seluruh prosedur perencanaan perkerasan kaku didasarkan pada kumulatif 18-kip equivalent single axle load (ESAL) selama umur rencana. Besar kumulatif ESAL selama umur rencana dikalikan dengan faktor distribusi arah dan faktor distribusi lajur untuk menentukan besarnya volume lalu lintas pada lajur rencana $\left(W_{18}\right)$.

\section{A. Koefisien Distribusi Arah}

Koefisien distribusi arah (D) biasanya bernilai 0,5 (50\%). Namun berdasarkan pengalaman, nilai $\mathrm{D}$ bervariasi antara 0,3 sampai 0,7 tergantung dari beban lalu lintas yang terjadi di masing-masing arah.

\section{B. Koefisien Distribusi Lajur}

Jika jalan tidak memiliki tanda batas lajur, maka jumlah lajur dan koefisien distribusi (C) kendaraan niaga dapat ditentukan berdasarkan lebar perkerasan atau jumlah lajur setiap arah seperti pada Tabel 1 dan Tabel 2. 
Tabel 1. Jumlah Lajur berdasarkan Lebar Perkerasan dan Koefisien Distribusi Kendaraan Niaga pada Lajur Rencana

\begin{tabular}{|c|c|c|c|}
\hline \multirow{2}{*}{ Lebar Perkerasan $(L p)$} & \multirow{2}{*}{ Jumlah Lajur $\left(n_{l}\right)$} & \multicolumn{2}{|c|}{ Koefisien Distribusi } \\
\cline { 3 - 4 } & & 1 Arah & 2 Arah \\
\hline$L p<5,50 \mathrm{~m}$ & 1 lajur & 1 & 1 \\
$5,50 \mathrm{~m} \leq L p<8,25 \mathrm{~m}$ & 2 lajur & 0,7 & 0,5 \\
$8,25 \mathrm{~m} \leq L p<11,25 \mathrm{~m}$ & 3 lajur & 0,5 & 0,475 \\
$11,23 \mathrm{~m} \leq L p<15,00 \mathrm{~m}$ & 4 lajur & - & 0,45 \\
$15,00 \mathrm{~m} \leq L p<18,75 \mathrm{~m}$ & 5 lajur & - & 0,425 \\
$18,75 \mathrm{~m} \leq L p<22,00 \mathrm{~m}$ & 6 lajur & - & 0,40 \\
\hline
\end{tabular}

Sumber: Bina Marga, 2003.

Tabel 2. Faktor Distribusi Lajur

\begin{tabular}{|c|c|}
\hline $\begin{array}{c}\text { Jumlah Lajur } \\
\text { Setiap Arah }\end{array}$ & $D_{L}(\%)$ \\
\hline 1 & 100 \\
2 & $80-100$ \\
3 & $60-80$ \\
4 & $50-75$ \\
\hline
\end{tabular}

Sumber: AASHTO, 1993.

\section{Konfigurasi Sumbu Kendaraan}

Konfigurasi sumbu untuk perencanaan terdiri atas 4 (empat) jenis kelompok sumbu sebagai berikut:

1. Sumbu tunggal roda tunggal (STRT).

Angka ekivalen STRT, dihitung menggunakan Persamaan 4.

$$
\mathrm{E}_{\mathrm{STRT}}=\left[\frac{\text { Bebansumbu(ton) }}{5,40}\right]^{4}
$$

2. Sumbu tunggal roda ganda (STRG).

Angka ekivalen STRG, dihitung menggunakan Persamaan 5.

$$
\mathrm{E}_{\mathrm{STRG}}=\left[\frac{\text { Bebansumbu(ton) })}{8,16}\right]^{4}
$$

3. Sumbu tandem roda ganda (STdRG).

Angka ekivalen STdRG, dihitung menggunakan Persamaan 6.

$$
\mathrm{E}_{\mathrm{STdRG}}=\left[\frac{\text { Bebansumbu(ton) }}{13,76}\right]^{4}
$$

4. Sumbu tridem roda ganda (STrRG). 
Angka ekivalen STrRG, dihitung menggunakan Persamaan 7.

$$
\mathrm{E}_{\mathrm{STrRG}}=\left[\frac{\text { Bebansumbu(ton) }}{18,45}\right]^{4}
$$

\section{Lalu Lintas Rencana}

Lalu lintas rencana adalah jumlah kumulatif sumbu kendaraan niaga pada lajur rencana selama umur rencana, meliputi proporsi sumbu serta distribusi beban pada setiap jenis sumbu kendaraan.

\section{Umur Rencana Perkerasan}

Umur rencana merupakan suatu periode tertentu dalam tahun, yang dirancang agar jalan yang direncanakan dan dipelihara dapat berfungsi selama periode tersebut. Umur rencana perkerasan jalan ditentukan atas pertimbangan klasifikasi fungsional jalan, pola lalu lintas serta nilai ekonomi jalan yang bersangkutan, yang dapat ditentukan antara lain dengan metode Benefit Cost Ratio, Internal Rate of Return, kombinasi metode tersebut atau cara lain yang tidak terlepas dari pola pengembangan wilayah. Umumnya perkerasan kaku dapat direncanakan dengan umur rencana (UR) 20 tahun sampai 40 tahun atau dapat menggunakan Tabel 3.

Tabel 3. Umur Rencana Perkerasan Baru

\begin{tabular}{|c|c|c|}
\hline $\begin{array}{c}\text { Jenis } \\
\text { Perkerasan }\end{array}$ & Elemen Perkerasan & $\begin{array}{l}\text { Umur Rencana } \\
\text { (tahun) }\end{array}$ \\
\hline \multirow{4}{*}{ Perkerasan Lentur } & $\begin{array}{l}\text { Lapisan aspal dan lapisan berbutir } \\
\text { cement treated base }\end{array}$ & 20 \\
\hline & Pondasi jalan & \multirow{4}{*}{40} \\
\hline & $\begin{array}{l}\text { Semua lapisan perkerasan untuk area yang } \\
\text { tidak diizinkan sering ditinggikan akibat } \\
\text { pelapisan ulang, misal: jalan perkotaan, } \\
\text { underpass, jembatan, terowongan. }\end{array}$ & \\
\hline & Cement treated base & \\
\hline Perkerasan Kaku & $\begin{array}{l}\text { Lapis pondasi, lapis pondasi bawah, lapis } \\
\text { beton semen }\end{array}$ & \\
\hline $\begin{array}{l}\text { Jalan Tanpa } \\
\text { Penutup }\end{array}$ & Semua elemen & $\begin{array}{l}\text { Minimum } \\
10\end{array}$ \\
\hline
\end{tabular}

Sumber: Bina Marga, 2013. 


\section{Faktor Pertumbuhan Lalu Lintas}

Faktor pertumbuhan lalu lintas didasarkan pada data pertumbuhan historis atau formulasi korelasi dengan faktor pertumbuhan lain yang akurat (Pd T-14-2003). Volume lalu lintas akan bertambah sesuai dengan umur rencana atau sampai tahap dimana kapasitas jalan dicapai dengan faktor pertumbuhan lalu lintas yang dapat ditentukan berdasarkan Persamaan 8.

$$
R=\frac{(1+i)^{\mathrm{UK}}-1}{i}
$$

dengan:

$R \quad: \quad$ Faktor pertumbuhan lalu lintas.

$i \quad: \quad$ Laju pertumbuhan lalu lintas per tahun (\%).

UR : $\quad$ Umur rencana (tahun).

atau menggunakan Tabel 4.

Tabel 4. Perkiraan Laju Pertumbuhan Lalu Lintas (i)

\begin{tabular}{|c|c|c|}
\hline & $2011-2020$ & $>2021-2030$ \\
\hline Arteri dan perkotaan (\%) & 5 & 4 \\
Rural (\%) & 3,5 & 2,5 \\
\hline
\end{tabular}

Sumber: Bina Marga, 2012.

\section{Serviceability}

Serviceability merupakan tingkat pelayanan yang diberikan oleh sistem perkerasan yang kemudian dirasakan oleh pengguna jalan. Nilai serviceability ini merupakan nilai yang menjadi penentu tingkat pelayanan fungsional suatu sistem perkerasan jalan. Secara numerik serviceability merupakan fungsi beberapa parameter, antara lain ketidakrataan, jumlah lubang, luas tambalan, dan lain-lain.

\section{A. Initial Present Serviceability Index}

Untuk perkerasan yang baru dibuka (open traffic) nilai indeks permukaan awal diberikan sebesar 4,0 - 4,5. Nilai ini dalam terminologi perkerasan diberikan sebagai nilai initial serviceability (Po).

\section{B. Terminal Serviceability Index}

Untuk perkerasan yang harus dilakukan perbaikan pelayanannya, nilai terminal serviceability index diberikan sebesar 2,0. Nilai terminal serviceability index dapat diperoleh berdasarkan Tabel 5 . 
Tabel 5. Indeks Permukaan pada Akhir Umur Rencana

\begin{tabular}{|c|c|c|c|c|}
\hline \multirow{2}{*}{ LER } & \multicolumn{4}{|c|}{ Fungsi Jalan } \\
\cline { 2 - 5 } & Lokal & Kolektor & Arteri & Tol \\
\hline$<10$ & $1,0-1,5$ & 1,5 & $1,5-2,0$ & - \\
$10-100$ & 1,5 & $1,5-2,0$ & 2,0 & - \\
$100-1000$ & $1,5-2,0$ & 2,0 & $2,0-2,5$ & - \\
$>1000$ & - & $2,0-2,5$ & 2,5 & 2,5 \\
\hline
\end{tabular}

Sumber: Metode Analisa Komponen, SNI. 1987.

\section{Reliabilitas}

Reliabilitas adalah nilai probabilitas kemungkinan tingkat pelayanan yang dapat dipertahankan selama masa pelayanan dipandang dari sisi pemakai jalan. Reliabilitas merupakan jaminan bahwa perkiraan beban lalu lintas yang akan menggunakan jalan tersebut dapat dipenuhi. Perkerasan kaku direncanakan dengan menggunakan klasifikasi jalan yang tinggi karena perkerasan ini akan difungsikan untuk menampung volume lalu lintas yang cukup tinggi. Informasi mengenai tingkat reliabilitas (R) yang digunakan dalam merencanakan perkerasan kaku dapat dilihat pada Tabel 6 .

Tabel 6. Nilai Reliabilitas untuk Berbagai Klasifikasi Jalan

\begin{tabular}{|c|c|c|}
\hline \multirow{2}{*}{ Klasifikasi Jalan } & \multicolumn{2}{|c|}{ Rekomendasi Tingkat Reliabilitas (\%) } \\
\cline { 2 - 3 } & Perkotaan & Antar kota \\
\hline Bebas hambatan & $85-99,9$ & $80-99,9$ \\
Arteri & $80-99$ & $75-95$ \\
Kolektor & $80-95$ & $75-95$ \\
Lokal & $50-80$ & $50-80$ \\
\hline
\end{tabular}

Sumber: AASHTO, 1993.

\section{A. Standar Deviasi}

Nilai standar deviasi mewakili kondisi lokal yang ada. Berdasarkan data dari jalan percobaan AASHTO ditentukan nilai So dari rentang sebesar 0,30 - 0,40 untuk rigid pavement. Hal ini berhubungan dengan total standar deviasi sebesar 0,35 dan 0,45 untuk lalu lintas untuk jenis perkerasan rigid dan flexible.

\section{B. Standar Normal Deviasi}

Tingkat reliabilitas berhubungan dengan nilai standar normal deviasi yang diberikan pada Tabel 7. 
Tabel 7. Standar Normal Deviasi

\begin{tabular}{|c|c|}
\hline $\begin{array}{c}\text { Reliabilitas, } \\
\mathrm{R}(\%)\end{array}$ & $\begin{array}{c}\text { Standard } \\
\text { Normal } \\
\text { Deviate, } Z_{R}\end{array}$ \\
\hline 50 & 0,000 \\
60 & $-0,253$ \\
70 & $-0,524$ \\
75 & $-0,674$ \\
80 & $-0,842$ \\
85 & $-1,036$ \\
90 & $-1,282$ \\
91 & $-1,341$ \\
92 & $-1,405$ \\
93 & $-1,476$ \\
94 & $-1,555$ \\
95 & $-1,645$ \\
96 & $-1,751$ \\
97 & $-1,881$ \\
98 & $-2,054$ \\
99 & $-2,326$ \\
99,9 & $-3,090$ \\
99,99 & $-3,750$ \\
\hline
\end{tabular}

Sumber: AASHTO, 1993.

\section{Loss of Support Factor}

Faktor kehilangan daya dukung (LS) termasuk dalam perencanaan perkerasan kaku untuk memperhitungkan potensi kehilangan daya dukung yang bertambah akibat erosi lapisan pondasi bawah atau perubahan pergerakan partikel tanah. Nilai LS dapat diperoleh berdasarkan Tabel 8 .

Tabel 8. Faktor Kehilangan Daya Dukung berdasarkan Tipe Material

\begin{tabular}{|l|c|}
\hline \multicolumn{1}{|c|}{ Type of Material } & $\begin{array}{c}\text { Loss of } \\
\text { Support } \\
\text { (LS })\end{array}$ \\
\hline $\begin{array}{l}\text { Cement Treated Granular Base } \\
(E=1000000 \text { to } 2000000 \mathrm{psi})\end{array}$ & 0,0 to 1,0 \\
\hline $\begin{array}{l}\text { Cement Aggregate Mixtures } \\
(E=500000 \text { to } 1000000 \mathrm{psi})\end{array}$ & 0,0 to 1,0 \\
\hline $\begin{array}{l}\text { Asphalt Treated Base } \\
(E=350000 \text { to } 1000000 \mathrm{psi})\end{array}$ & 0,0 to 1,0 \\
\hline $\begin{array}{l}\text { Bituminous Stabilized Mixtures } \\
(E=40000 \text { to } 300000 \mathrm{psi})\end{array}$ & 0,0 to 1,0 \\
\hline $\begin{array}{l}\text { Lime Stabilized } \\
(E=20000 \text { to } 70000 \mathrm{psi})\end{array}$ & 1,0 to 3,0 \\
\hline $\begin{array}{l}\text { Unbound Granular Materials } \\
(E=15000 \text { to } 45000 \mathrm{psi})\end{array}$ & 1,0 to 3,0 \\
\hline $\begin{array}{l}\text { Fine Grained } \text { or Natural Subgrade Materials } \\
(E=3000 \text { to 40000psi) }\end{array}$ & 2,0 to 3,0 \\
\hline
\end{tabular}

Sumber: AASHTO, 1993. 


\section{Koefisien Pelimpahan Beban}

Koefisien pelimpahan beban $(J)$ adalah faktor yang mempengaruhi kemampuan perkerasan kaku dalam melimpahkan atau mendistribusikan beban pada daerah yang terputus seperti daerah sambungan atau retakan. Nilai koefisien pelimpahan beban berdasarkan jenis perkerasannya dapat dilihat dari Tabel 10.

Tabel 10. Koefisien Pelimpahan Beban

\begin{tabular}{|l|c|c|c|c|}
\hline \multicolumn{1}{|c|}{ Bahu } & \multicolumn{2}{|c|}{ Aspal } & \multicolumn{2}{c|}{ Beton } \\
\hline \multicolumn{1}{|c|}{ Pelimpahan Beban } & Ya & Tidak & Ya & Tidak \\
\hline \multicolumn{1}{|c|}{ Jenis Perkerasan } & \multicolumn{3}{|c|}{} \\
\hline $\begin{array}{l}\text { Perkerasan bersambung tanpa atau dengan } \\
\text { tulangan } \\
\text { (JCP / JRCP) }\end{array}$ & 3,2 & $3,8-4,4$ & $2,5-3,1$ & $3,6-4,2$ \\
\hline $\begin{array}{l}\text { Perkerasan beton menerus dengan tulangan } \\
(\mathrm{CRCP})\end{array}$ & $2,9-3,2$ & N/A & $2,3-2,9$ & N/A \\
\hline
\end{tabular}

Sumber: AASHTO, 1993.

\section{Koefisien Drainase}

Metode ini diberikan koefisien pengaruh dari drainase seperti diberikan pada Tabel 11. Definisi kualitas drainase dapat dilihat pada Tabel 12.

Tabel 11. Koefisien Drainase untuk Perkerasan Kaku

\begin{tabular}{|c|c|c|c|c|}
\hline \multirow{2}{*}{$\begin{array}{c}\text { Kualitas } \\
\text { Drainase }\end{array}$} & \multicolumn{4}{|c|}{$\begin{array}{c}\text { Persen Waktu Struktur Perkerasan dipengaruhi oleh } \\
\text { Kadar Air yang Mendekati Jenuh }\end{array}$} \\
\cline { 2 - 5 } & $<1 \%$ & $1 \%-5 \%$ & $5 \%-25 \%$ & $>25 \%$ \\
\hline Sangat Baik & $1,25-1,20$ & $1,20-1,15$ & $1,15-1,10$ & 1,10 \\
Baik & $1,20-1,15$ & $1,15-1,10$ & $1,10-1,00$ & 1,00 \\
Sedang & $1,15-1,10$ & $1,10-1,00$ & $1,00-0,90$ & 0,90 \\
Buruk & $1,10-1,00$ & $1,00-0,90$ & $0,90-0,80$ & 0,80 \\
Sangat Buruk & $1,00-0,90$ & $0,90-0,80$ & $0,80-0,70$ & 0,70 \\
\hline
\end{tabular}

Sumber: AASHTO, 1993.

Tabel 12. Definisi Kualitas Drainase

\begin{tabular}{|l|c|}
\hline \multicolumn{1}{|c|}{$\begin{array}{c}\text { Kualitas } \\
\text { Drainase }\end{array}$} & \multicolumn{1}{c|}{$\begin{array}{c}\text { Waktu Air } \\
\text { Mengalir }\end{array}$} \\
\hline Sangat Baik & 2 jam \\
Baik & 1 hari \\
Sedang & 1 minggu \\
Buruk & 1 bulan \\
Sangat Buruk & Air tidak mengalir \\
\hline
\end{tabular}

Sumber: AASHTO, 1993. 


\section{METODE PENELITIAN}

Bagan alir penelitian dapat dilihat pada Gambar 5.

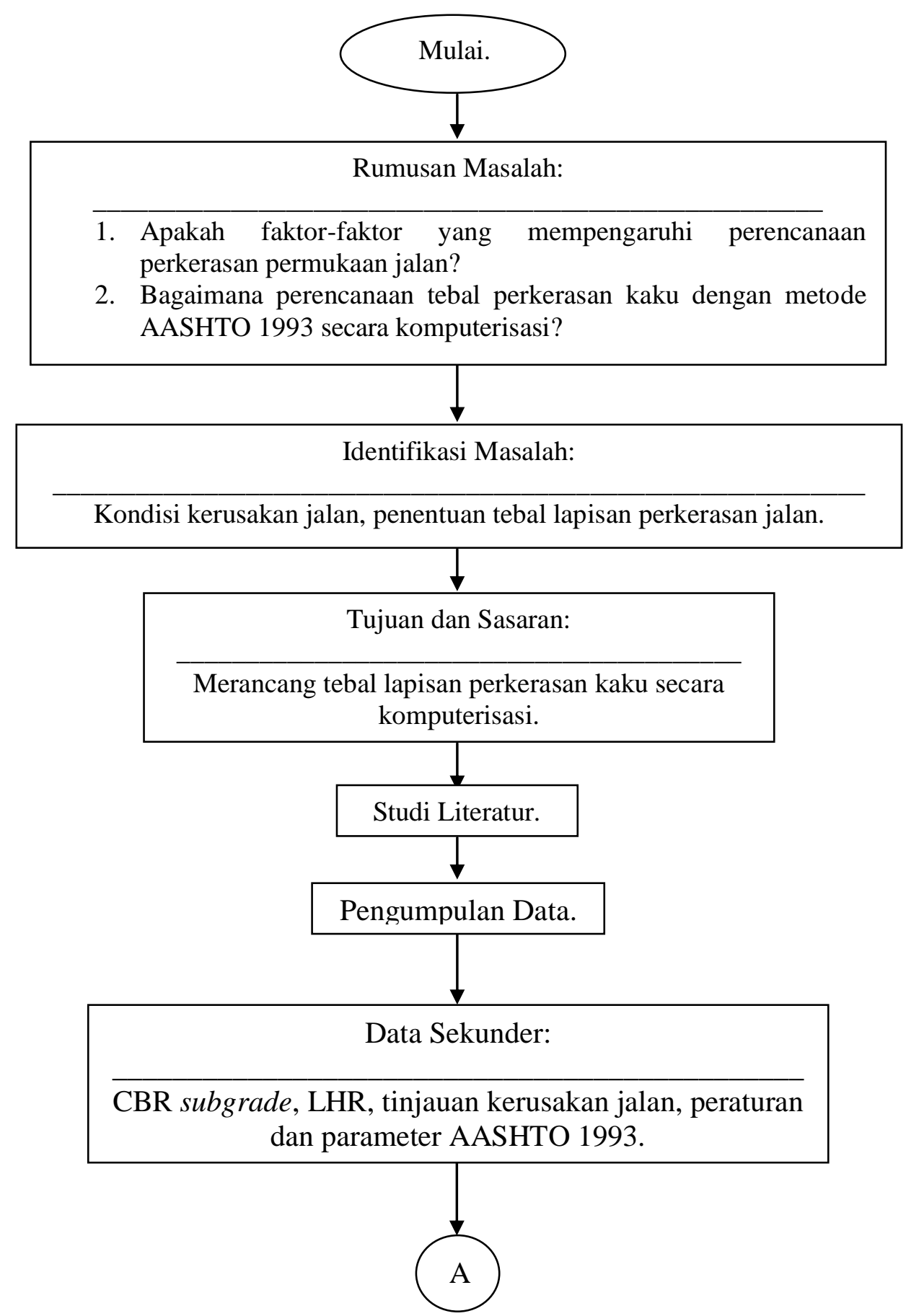

Gambar 5. Bagan Alir Penelitian 


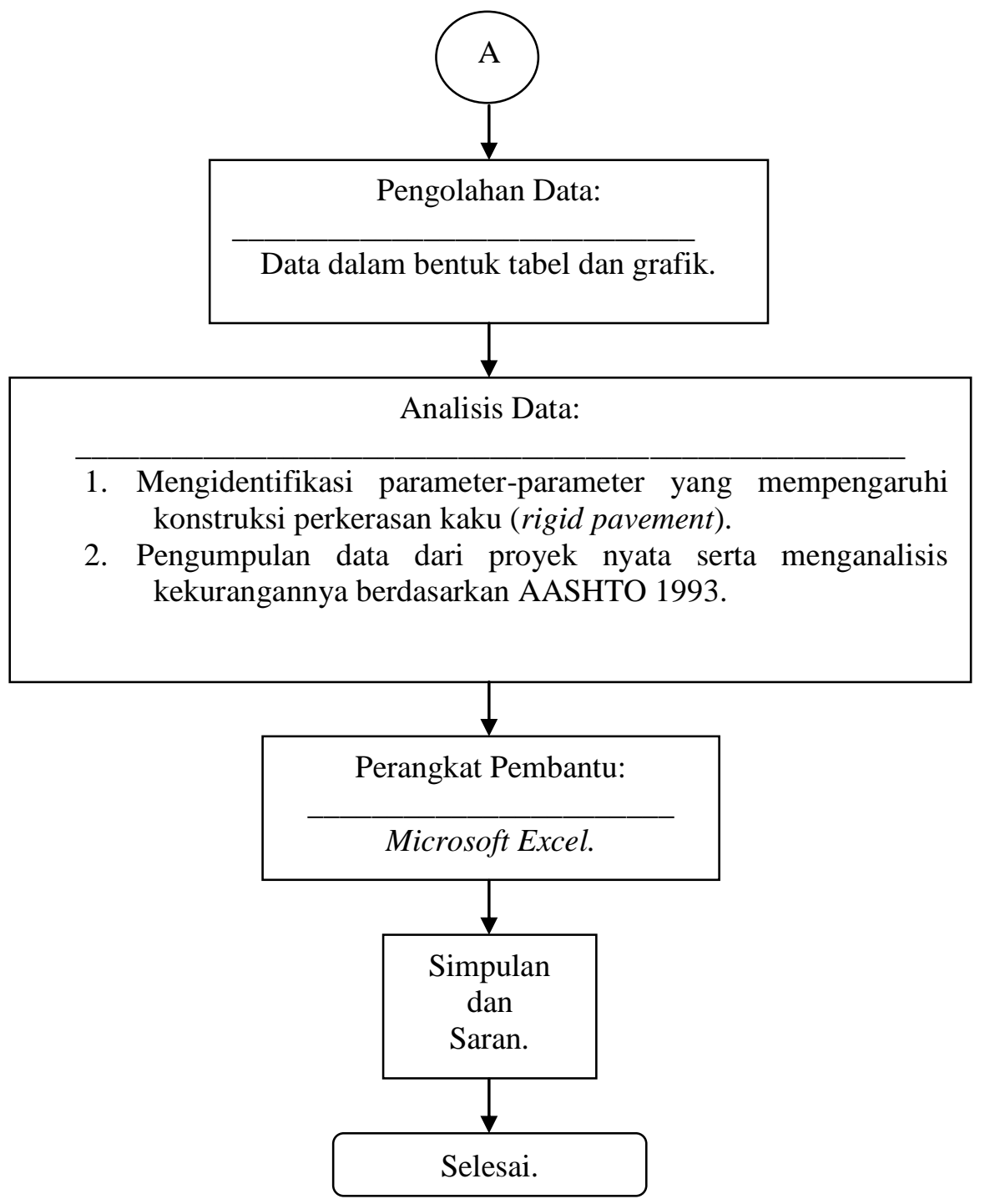

Gambar 5. Bagan Alir Penelitian (Lanjutan)

\section{ANALISIS DATA DAN PEMBAHASAN}

Besarnya pertumbuhan lalu lintas telah ditetapkan untuk semua jenis kendaraan selama umur rencana. Rekapitulasi laju pertumbuhan di Tol Cipali dapat dilihat pada Tabel 13.

Tabel 13. Rekapitulasi Laju Pertumbuhan di Tol Cipali

\begin{tabular}{|c|c|c|c|}
\hline No. & \multirow{2}{*}{ Keterangan } & Gerbang & $\begin{array}{c}\text { Laju } \\
\text { Pertumbuhan (\%) }\end{array}$ \\
\hline 1 & \multirow{2}{*}{ Bulanan } & Cikopo & $15,8 \%$ \\
\cline { 3 - 4 } & & Palimanan & $21,0 \%$ \\
\hline 3 & \multirow{2}{*}{ Tahunan } & Cikopo & $104,5 \%$ \\
\cline { 3 - 4 } & & Palimanan & $37,7 \%$ \\
\hline 4 & &
\end{tabular}


Besarnya total beban gandar standar ekivalen untuk semua jenis kendaraan selama umur rencana 30 tahun dan laju pertumbuhan sebesar 15,8\% pada Tol Cipali dapat dilihat pada Tabel 14 .

Tabel 14. Total Kumulatif Beban Gandar Standar Ekivalen pada Tol Cipali

\begin{tabular}{|c|c|c|c|c|}
\hline No & Kendaraan & $\begin{array}{c}\begin{array}{c}\text { Berat } \\
\text { (ton) }\end{array} \\
\end{array}$ & $\begin{array}{c}\text { AADT } \\
\text { veh/h }\end{array}$ & Sum. ESAL \\
\hline 1 & Kend Ringan (1.1) & 2 & 171532 & 0 \\
\hline 2 & Bus (1.2) & 8 & 3501 & 35117204,23 \\
\hline 3 & Truk 2 gandar (1.2) & 14 & 21791 & 2050015657 \\
\hline 4 & Truk 3 gandar (1.22) & 22 & 1993 & 262221278 \\
\hline 5 & Truk 4 gandar $(1.2-2.2)$ & 32 & 282 & 62103160,52 \\
\hline 6 & Truk 5 gandar $(1.2-222)$ & 40 & 157 & 132077304,4 \\
\hline \multicolumn{3}{|c|}{ Total } & 199256 & 2541534604 \\
\hline
\end{tabular}

Pada Persamaan 9, perlu menghitung nilai $W_{18}$ nominal.

$W_{18}$ nominal $=\log 10($ Sum. ESAL $)$

$W_{18}$ nominal $=\log 10(2541534604)$

$W_{18}$ nominal $=9,40510$

Pada Persamaan 10 dan Persamaan 11 perlu menentukan tebal pelat beton rencana $(D)$ untuk menentukan kesesuaian antara tebal pelat beton yang dianalisis menggunakan metode AASHTO 1993 dengan hasil berupa data sekunder di lapangan. Asumsi tebal pelat beton sebesar $39 \mathrm{~cm}$.

Adapun Persamaan 10 diperoleh hasil:

$\mathrm{A}=Z_{R} \mathrm{x}$ So $+7,35 \mathrm{x} \log 10(D+1)-0,06+\frac{\log 10\left[\frac{\Delta P S T}{45-1,5}\right]}{1+\frac{1,624 \mathrm{X} 107}{(D+1)^{8,46}}}$

$\mathrm{A}=-1,282 \times 0,35+7,35 \times \log 10(15,35+1)-0,06+\frac{\log 10\left[\frac{2}{45-1,5}\right]}{1+\frac{1,6244107}{(15,85+1)^{8 / 46}}}$

$\mathrm{A}=8,23556$

Sedangkan Persamaan 11 diperoleh hasil:

$\mathrm{B}=\left(4,22-0,32 \times P_{t}\right) \times \log 10\left[\frac{S_{C} \times C d \times\left(D^{0,75}-1,132\right)}{215,63 \times J\left[D^{0,75}-\frac{18,42}{\left.\left[E_{C} / k\right)^{0,25}\right]}\right]}\right]$

$\mathrm{B}=(4,22-0,32 \times 2,5) \times \log 10\left[\frac{700 \times 1,25 \times\left(15,35^{0,75}-1,132\right)}{215,63 \times 2,6\left[15,35^{0,75}-\frac{18,42}{[4560179,19 / 175)^{0,25}}\right]}\right]$

$B=0,73419$ 
Total nilai $\mathrm{A}+\mathrm{B}$, yaitu:

$8,23556+0,73419=8,96975$

Adapun selisih/perbedaannya dihitung dengan cara:

Toleransi $=\frac{\log 10(\mathrm{~W} 18)-(\mathrm{A}+\mathrm{B})}{(\mathrm{A}+\mathrm{B})} \times 100 \%$

Toleransi $=\frac{9,40510-(8,96975)}{(8,96975)} \times 100 \%$

Toleransi $=4,85 \%$, syarat terpenuhi.

Untuk laju pertumbuhan sebesar 5\% dan umur rencana perkerasan 30 tahun dengan asumsi tebal pelat beton sebesar $30 \mathrm{~cm}$, diperoleh hasil:

Persamaan $9=8,52028$

Persamaan $10=7,45716$

Persamaan $11=0,75411$

Toleransi $=3,76 \%$, syarat terpenuhi.

Sehingga tebal pelat beton untuk umur rencana perkerasan hasil analisis dengan laju pertumbuhan sebesar 15,8\% diperoleh hasil sebesar $39 \mathrm{~cm}$, sedangkan dengan laju pertumbuhan sebesar 5\% sesuai dengan perkiraan pertumbuhan lalu lintas pada Bina Marga, 2012 diperoleh tebal pelat beton sebesar $30 \mathrm{~cm}$.

\section{KESIMPULAN DAN SARAN}

Dari analisis yang telah dilakukan dapat ditarik simpulan sebagai berikut:

1. Volume lalu lintas rencana yang dianalisis dengan perangkat lunak Microsoft Excel diperoleh berdasarkan gerbang Tol Cikopo pada saat awal beroperasi, yaitu pada bulan Juni tahun 2015. Hal ini dikarenakan pada tahap perencanaan awal, gate masuk (Cikopo) memberikan jumlah yang paling besar, yaitu 199256 kendaraan. Jumlah kendaraan terbanyak yaitu kendaraan mobil penumpang.

2. Angka pertumbuhan lalu lintas di Tol Cipali mengalami fluktuasi. Peningkatan volume lalu lintas terbesar terdapat pada laju pertumbuhan tahunan pada bulan Juni sebesar 104,5\% sebagai generated traffic pada awal tahun beroperasi.

3. Tebal pelat beton untuk umur rencana perkerasan dengan laju pertumbuhan sebesar 15,8\% diperoleh hasil sebesar $39 \mathrm{~cm}$, sedangkan dengan laju pertumbuhan sebesar 5\% sesuai dengan perkiraan pertumbuhan lalu lintas pada Bina Marga, 2012 diperoleh tebal pelat beton sebesar $30 \mathrm{~cm}$. 
4. Penyusunan faktor yang mempengaruhi pendekatan empiris dalam desain struktur perkerasan kaku suatu ruas jalan secara komputerisasi dapat mempermudah proses perhitungan dan dapat dilakukan secara iterasi, serta lebih sistematis dapat dilihat pada demo Microsoft Excel.

Untuk perkembangan penelitian selanjutnya diberikan beberapa saran sebagai berikut:

1. Perhitungan penentuan tebal perkerasan kaku diperlukan data yang lebih lengkap, baik data lalu lintas volume kendaraan, maupun data spesifikasi teknik jalan.

2. Diperlukan penelitian lebih lanjut mengenai kualitas drainase untuk perkerasan kaku.

3. Diperlukannya penelitian lebih lanjut terhadap parameter desain modulus resilient tanah dasar pada metode AASHTO 1993 dalam fungsinya sebagai salah satu parameter desain dalam merencanakan tebal perkerasan khususnya untuk melihat kondisi tanah dasar.

4. Penyusunan pedoman praktis yang user friendly (mudah dipahami) mengingat perencanaan tebal perkerasan dengan menggunakan metode AASHTO 1993 yang cukup rumit.

\section{DAFTAR PUSTAKA}

1. AASHTO, 1993, Guide for Design of Pavement Structure, American Association of State Highway and Transportation Officials, Washington, USA.

2. Christopher, B.R., Schwartz, C., and Boudreau, R., 2006, Geotechnical Aspects of Pavements: Reference Manual/Participant Workbook, Technical Report, Publication No. FHWA NHI-05-037, U.S. Department of Transportation, National Highway Institute, Washington D.C.

3. Departemen Pekerjaan Umum Direktorat Jenderal Bina Marga, 1983. Manual Pemeriksaan Perkerasan Jalan dengan alat Benkelman Beam No.01/MN/B/1983. Direktorat Jenderal Bina Marga Departemen Pekerjaan Umum. Jakarta.

4. Departemen Permukiman dan Prasarana Wilayah, 2003, Perencanaan Perkerasan Jalan Beton Semen, Pedoman Konstruksi Bangunan, Pd.T-14-2003, Departemen Permukiman dan Prasarana Wilayah.

5. Departemen Permukiman dan Prasarana Wilayah, 2004, Pelaksanaan Perkerasan Jalan Beton Semen, Pedoman Konstruksi Bangunan, Pd.T-05-2004-B, Departemen Permukiman dan Prasarana Wilayah. 
6. Direktorat Jenderal Bina Marga. 1997. Manual Kapasitas Jalan Indonesia, Bandung.

7. Direktorat Jenderal Bina Marga. 1997. Tata Cara Perencanaan Geometrik Jalan Antar Kota. Jakarta.

8. Kementerian Pekerjaan Umum, Direktorat Jenderal Bina Marga, 2012, Manual Desain Perkerasan Jalan, No. 22.2/KPTS/Db/2012.

9. Kementerian Pekerjaan Umum, Direktorat Jenderal Bina Marga, 2013, Manual Desain Perkerasan Jalan, Nomor 02/M/BM/2013, Kementerian Pekerjaan Umum, Jakarta.

10. Keputusan Menteri Pemukiman dan Prasarana Wilayah No.353/KPTS/2001 tentang Ketentuan Teknik, Tatacara Pembangunan dan Pemeliharaan Jalan Tol.

11. Lintas Marga Sedaya, PT. 2015. Detail Engineering Design Pembangunan Jalan Tol Cikopo-Palimanan, Subang.

12. RSNI, 2004, Pedoman Pencacahan Lalu Lintas dengan Cara Manual, Departemen Pekerjaan Umum, Jakarta.

13. SNI $03-6388$ - 2000 Mengenai Spesifikasi Agregat Tanah Lapis Pondasi Bawah, Lapis Pondasi, dan Lapis Permukaan.

14. Surat Edaran Direktorat Jenderal Perhubungan Darat, SE.02/AJ/AL.108/DRJ/2008, Tentang Paduan Batasan Maksimum Perhitungan JBI (Jumlah Berat yang di Izinkan) dan JBKI (Jumlah Berat Kombinasi yang di Ijinkan) untuk Mobil Barang, Kenderaan Khusus, Kendaraan Penarik, berikut Kereta Tempelan/ Kereta Gandengan, Jakarta.

15. Susilo, B. H, 2009, Laporan Kajian Lalu Lintas Rencana Teknik Akhir Jalan Tol Kunciran-Serpong.

16. Yoder, E. J. dan Witczak, M. W., 1975, Principles of Pavement Design. Second Edition, John Wiley and Sons Inc., New York. 


\section{LAMPIRAN}

1. Modulus Reaksi Tanah Dasar Efektif dengan Koreksi Nilai LS

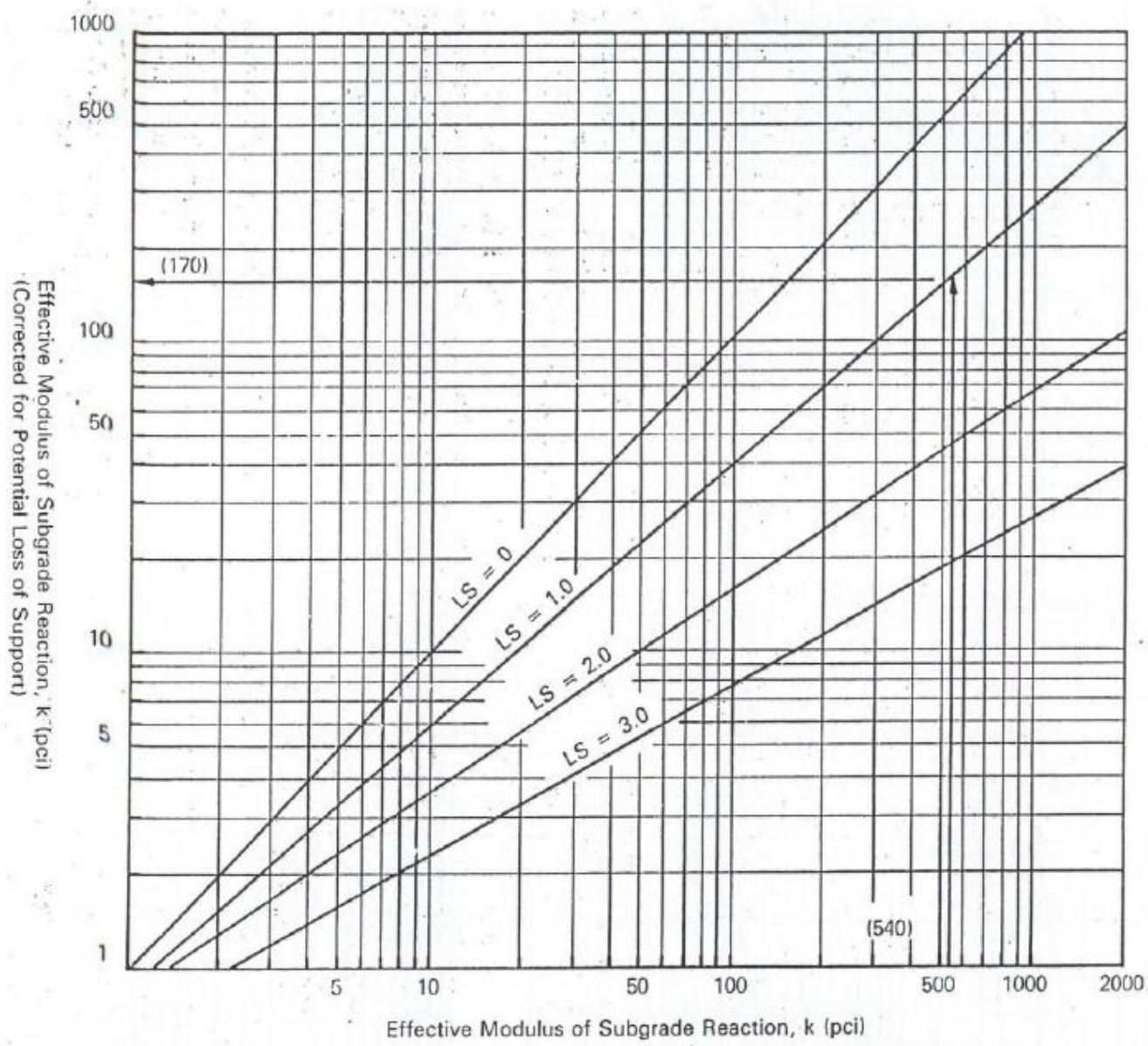


2. A. Rekapitulasi Penentuan Tebal Perkerasan Kaku dengan Laju Pertumbuhan 5\%
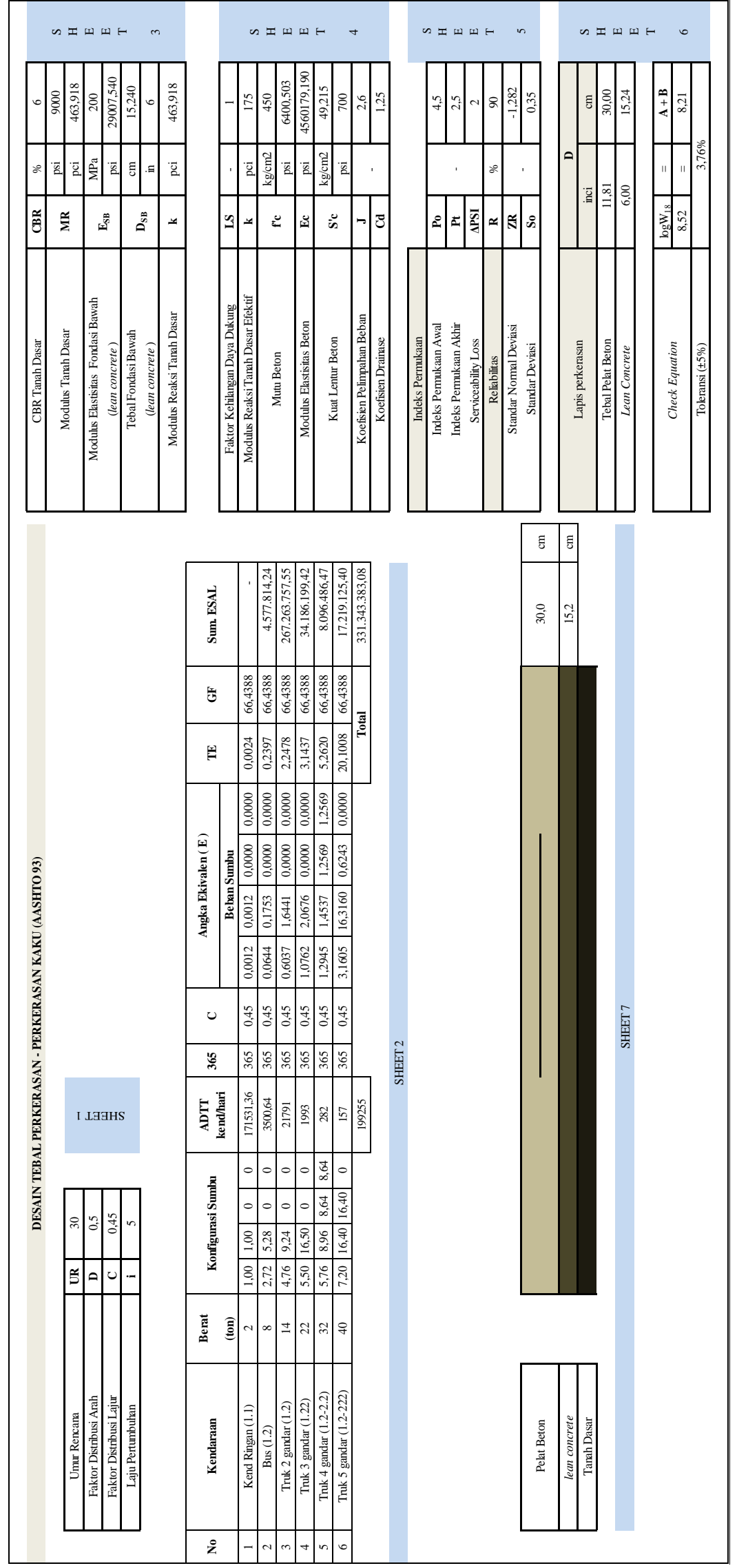
2. B. Rekapitulasi Penentuan Tebal Perkerasan Kaku dengan Laju Pertumbuhan $15,8 \%$

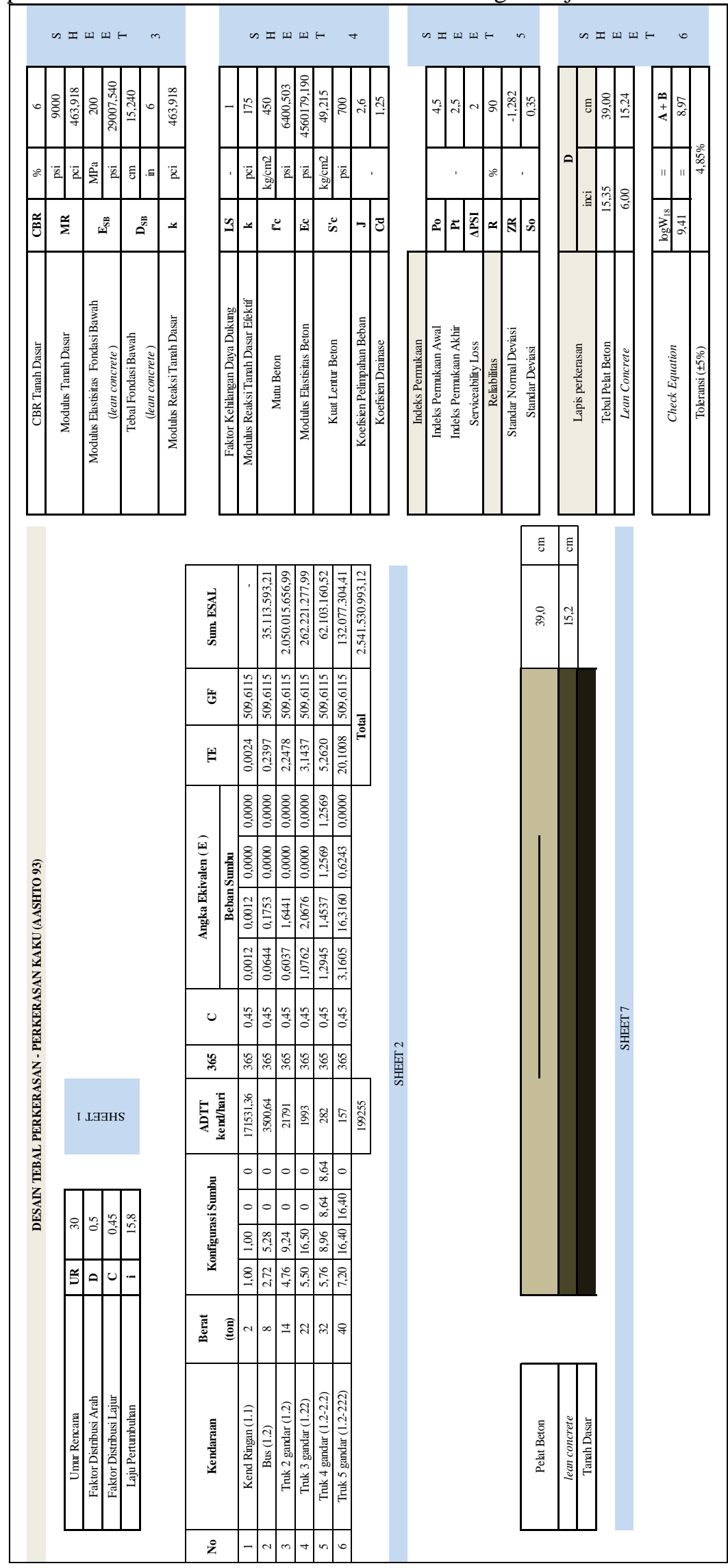

